\title{
Variation of Water Availability in Initial Development of Safflower
}

\author{
Nayara F. F. da S. Cruz ${ }^{1}$, Luiz A. Zanão Júnior ${ }^{1}$, Reginaldo F. Santos ${ }^{1}$, Luciene K. Tokura ${ }^{1}$, \\ Laís F. J. do Nascimento ${ }^{1}$, Jair A. C. Siqueira ${ }^{1}$, Alessandra M. T. Alovisi ${ }^{2}$, Luzia A. da S. Cruz ${ }^{3}$, \\ Lorenzo C. M. Castanhari ${ }^{1}$, Maisa Y. F. Otake ${ }^{4}$, Marcos A. Polinarski ${ }^{1}$, Pablo Chang ${ }^{1}$, \\ Vander F. Silveira ${ }^{1} \&$ Bruna S. Schuster ${ }^{5}$ \\ ${ }^{1}$ Graduation Program, Master's in Engineering of Energy in Agriculture, State University of West Paraná, \\ Cascavel, Paraná, Brazil \\ ${ }^{2}$ Post-Graduation Program in Agronomy, Federal University of Grande Dourados, Dourados, Mato Grosso do Sul, \\ Brazil \\ ${ }^{3}$ Graduation in Science with a degree in Mathematics, University of Parana, Umuarama, Paraná, Brazil \\ ${ }^{4}$ Post-Graduation Program in Tropical Biodiversity, Federal University of Amapá, Macapá, Amapá, Brazil \\ ${ }^{5}$ Graduation in Civil Engineering, State University of West Paraná, Cascavel, Paraná, Brazil \\ Correspondence: Laís F. J. do Nascimento, Graduation Program, Master's in Engineering of Energy in \\ Agriculture, State University of West Paraná, Rua Universitária, 2069-Jardim Universitário, CEP: 85819-110, \\ Cascavel, Paraná, Brazil. Tel: 55-(45)-3220-3151. E-mail: laisfjuchem@gmail.com
}

Received: September 19, 2018

doi:10.5539/jas.v11n3p558
Accepted: November 21, 2018

Online Published: February 15, 2019

\begin{abstract}
The availability of water is one of the most important factors for the development of the seeds. Thus, studies related to adequate humidity for germination, emergence and early development of safflowers, is necessary for the productive use of this culture. Thus, the objective of study was to evaluate the initial development of two varieties of seeds of Safflowers (IAPAR and IMA2103) in six levels of water availability in substrate: $0,10,20$, 30,40 and $50 \%$. At 15 days the seedling emergence were evaluate. At 30 days were evaluate plant height, root length, stem diameter, number of leaves, fresh weight of the aerial part and root, dry weight of shoot and root. The treatment without irrigation, there was decrease the emergence, emergence speed for both genotypes. Treatments above $30 \%$ of water availability in the two varieties presented emergency superior to $50 \%$. Lower irrigation rates favored root length and dry mass.
\end{abstract}

Keywords: humidity, emergence, seedlings, Carthamus tinctorius L.

\section{Introduction}

Carthamus tinctorius L. is an annual oilseed of great commercial importance in Mexico and India, although it is grown in the USA, Australia, Argentina, USA and other countries. It is a crop resistant to needs of low availability of water (Emerson et al., 2009), and seed oil can be used in food, in industrial and as raw materials to produce biofuels (Emongor, 2010).

In Brazil, the study of conditions for the germination and emergence of safflower seeds contributes to the commercial exploitation of the species, which is relatively new in the national market. According to Abud et al. (2010b), several environmental factors contribute to the development of differentiated seed components and can vary the morphological characteristics of the plant through color, seed format and size.

Among the environmental factors that stimulate seed development are the oxygen, temperature and water availability that must be in favorable conditions for their germination (Carvalho \& Nakagawa, 2000). Among the factors, the ideal water supply is essential for the seed to initiate the germination process, becoming a limiting factor to the growth and development of the seedling (Beltrão, Fideles Filho, \& Figueirêdo, 2002).

When the seed is exposed to situations of low water availability, its absorption is compromised, and seedling growth is affected, reflecting a decrease of the expansion and cellular elongation (Moterle et al., 2008). And when cultivated under conditions of water excess, the productivity of the safflower is reduced, and when this excess is greater than five days there is no grain production (Neto et al., 2012). 
According to Guo et al. (2014), the drought influences the productivity of crops around the world. Stress on drought and genetic history of drought are important factors for the development of safflower (Singh, 2006).

When safflower crops are sown only in soil moisture nutrients can be maintained up to 60 days after flowering of the branches and chapters, with flowering being initiated in few sampled cultivars. Thus, the study is generally necessary because the safflower is not a priority culture but rather a rotation crop, with few studies on moisture of the crop without residual requirements of other cultivars (Singh \& Nimbkar, 2016).

Soil humidity content for germination and early stages of seedling development are useful information for evaluating the best sowing season and seedling production, increasing the chances of population survival and productivity. Therefore, information about the adaptation and the limiting factors caused by lack or excess humidity in the soil are essential for the economic use of this crop. Based on the hypothesis that the safflower presents different development according to substrate humidity, this study has the objective of submitting seeds of two strains of IAPAR and IMA2103, in different levels of wetting for the evaluation of the emergence and the morphology of the seedlings.

\section{Material and Method}

The work was carried out in a protected environment of high-density polyethylene high tunnel plastic greenhouse in the experimental area of the State University of the West of Paraná, Cascavel campus with geographic coordinates of $24^{\circ} 59^{\prime} 21^{\prime \prime} \mathrm{S}$ and $53^{\circ} 26^{\prime} 59^{\prime \prime} \mathrm{W}$ and altitude of approximately $755 \mathrm{~m}$, in the period between May and June 2017, totaling 45 days. The climate of the region, according to Koppen's classification, is Cfa type, hot temperate (mesothermic), humid and the average temperature of the hottest month is above $22^{\circ} \mathrm{C}$.

The evaluation was carried out in two strains of Carthamus tinctorius L. (Compositae or also known as Asteraceae), one from the Matogrossence Institute of Cotton (IMA2103) and another from the Agronomic Institute of Paraná (IAPAR). These were assigned to the Postgraduate Program in Energy Engineering in Agriculture of the State University of the Western Paraná of Cascavel for scientific research.

The experimental design was a randomized block design with four replications in a $4 \times 6$ factorial scheme. The first factor was composed of two strains of safflower, and the second factor consisted of six water retention of 0 (control), 10, 20, 30, 40 and 50\% of water in substrate. Each experimental unit was constituted by plastic cups with capacity of $0.5 \mathrm{~L}$, with surface of approximately $56.74 \mathrm{~cm}^{2}$. The plastic cups were punched at their base with four circumferences of approximately $0.0025 \mathrm{~m}$ in diameter for the flow of water and added approximately $0.5 \mathrm{~L}$ of substrate. The Figure 1 represents the culture of the safflower.

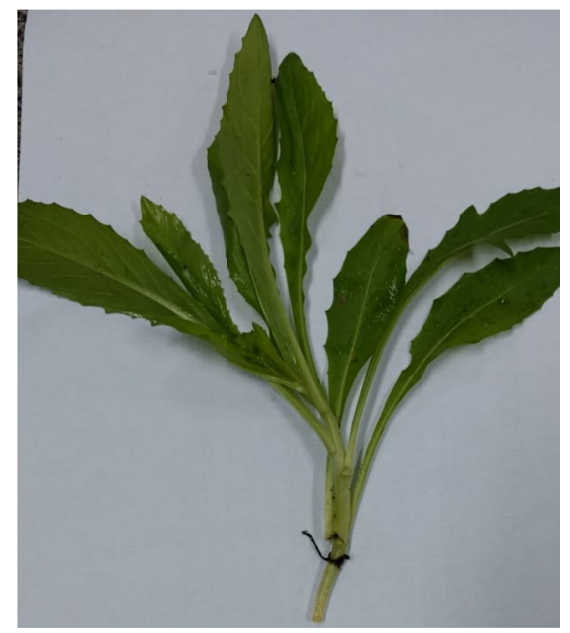

Figure 1. Safflower seedlings

To obtain the seedlings, five seeds of safflowers of each lineage were placed separately per cup, at a depth of $0.02 \mathrm{~m}$. The substrate used was the Humusfertil ${ }^{\circledR}$ Seed Germination with Pinus bark composition, substrate sand, vermicompost and vermiculite with the characteristics presented in Table 1. 
Table 1. Characteristics of the substrate used for the sowing of safflower

\begin{tabular}{lllll}
\hline Electrical conductivity & Density $\left(\mathbf{k g} / \mathbf{m}^{\mathbf{3}}\right)$ & Hydrogen potential & $\begin{array}{l}\text { Maximum humidity } \\
(\mathbf{\%}) \mathbf{w} / \mathbf{w}\end{array}$ & $\begin{array}{l}\text { Water retention capacity } \\
(\%) \text { by weight/weight) }\end{array}$ \\
\hline $1.5 \pm 0.3$ & 680 & $6 \pm 0.5$ & 60 & 60 \\
\hline
\end{tabular}

Immediately after sowing, the substrate was added distilled water in the percentages of $0,10,20,30,40$ and $50 \%$, and the water availability was restored every five days. After 15 days of sowing, daily recording the number of emerged seedlings the following indices were determined:

Percentage of Emergency (E), expressed as a percentage (\%):

$$
\mathrm{E}=\frac{\text { Number of emerged seeds }}{\text { Total seed }} \times 100
$$

Emergency Velocity Index (EVI), which was proposed by Maguire (1962), expressed in seeds/day:

$$
\mathrm{EVI}=\frac{\mathrm{E}_{1}}{\mathrm{~N}_{1}}+\frac{\mathrm{E}_{2}}{\mathrm{~N}_{2}}+\ldots \frac{\mathrm{E}_{\mathrm{n}}}{\mathrm{N}_{\mathrm{n}}}
$$

where,

$E_{1}, E_{2} \ldots$ En: number of normal seedlings counted, in the first, second and last count; $N_{1}, N_{2} \ldots$ Nn: number of days of sowing, in the first, second and last.

Average Time of Emergency (ATE): according to Laboriau and Valadares (1976), expressed in days:

$$
\mathrm{ATE}=\frac{\sum \mathrm{n}_{\mathrm{i}} \mathrm{t}_{\mathrm{i}}}{\sum \mathrm{n}_{\mathrm{i}}}
$$

where,

$\mathrm{ni}=$ number of seeds germinated in the interval between each count; $\mathrm{ti}=$ time elapsed between the beginning of the emergency and the $i$ th count.

Average Velocity of Emergence (AVE): expressed in days ${ }^{-1}$ :

$$
\mathrm{AVE}=\frac{1}{\mathrm{t}}
$$

where,

$\mathrm{t}=$ mean time of emergency.

After 15 days of this, the sowing was done again, duplicating the experiment. All experimental units were maintained until 30 days after sowing, after which the plants were extracted for the characterization of the plant height $(\mathrm{PH})$, root length (RL), stem diameter (SD), green weight (GW), Green Root Weight (GRW), Dry Air Weight (DAW), Dry Root Weight (DRW) and Number of Leaves (NL).

These analyzes were carried out at the University's own Soil Laboratory with the following equipment's: analytical balance with precision of 0.002 , greenhouse at $65{ }^{\circ} \mathrm{C}$ for 72 hours, Starrett digital caliper, and graduated tape in $\mathrm{mm}$.

The results were submitted to analysis of variance ANOVA and the comparison of the means by the test of Tukey to $5 \%$ of probability realized by software $\operatorname{SISVAR}^{\circledR}$ (Ferreira, 2011).

\section{Results and Discussion}

The analysis of variance indicated that the treatment with no addition of water resulted in lower values of Emergency Score (E), Emergency Velocity Index (EVI), Mean Time of Emergency (ATE) and Average Velocity of Emergence (AVE) of seeds of the IMA2103 and IAPAR varieties (Table 2). 
Table 2. Average values of Emergency Percentage (E), Emergency Velocity Index (EVI), Average Time of Emergency (ATE) and Average Velocity of Emergence (AVE) of seed of the IMA2103 and IAPAR varieties seeded and subjected to irrigation of $0,10,20,30,40$ and 50\% of water in substrate, in Cascavel, Paraná, during the period of May (experiment 1) and June (experiment 2) of 2017

\begin{tabular}{|c|c|c|c|c|c|c|c|c|}
\hline \multirow{2}{*}{ Treatment } & \multicolumn{2}{|c|}{ E (\%) } & \multicolumn{2}{|c|}{ EVI (seeds/day) } & \multicolumn{2}{|c|}{ ATE (day) } & \multicolumn{2}{|c|}{$\operatorname{AVE}\left(\right.$ day $\left.^{-1}\right)$} \\
\hline & IAPAR & IMA & IAPAR & IMA & IAPAR & IMA & IAPAR & IMA \\
\hline \multicolumn{9}{|c|}{ Experiment 1} \\
\hline $0 \%$ & $15 \mathrm{aA}$ & $10 \mathrm{aA}$ & $0.100 \mathrm{aA}$ & $0.085 \mathrm{aA}$ & $0.625 \mathrm{aA}$ & $0.500 \mathrm{aA}$ & $0.415 \mathrm{aA}$ & $0.500 \mathrm{aA}$ \\
\hline $10 \%$ & $60 \mathrm{aA}$ & $50 \mathrm{bA}$ & $0.387 \mathrm{aA}$ & $0.410 \mathrm{bA}$ & $2.832 \mathrm{bA}$ & $1.082 \mathrm{aA}$ & $0.402 \mathrm{aA}$ & $0.937 \mathrm{aB}$ \\
\hline $20 \%$ & $50 \mathrm{aA}$ & $20 \mathrm{bA}$ & $0.342 \mathrm{aA}$ & $0.175 \mathrm{aA}$ & $2.415 \mathrm{bA}$ & $1.125 \mathrm{aA}$ & $0.525 \mathrm{aA}$ & $0.600 \mathrm{aA}$ \\
\hline $30 \%$ & $65 \mathrm{aA}$ & $50 \mathrm{bA}$ & $0.465 \mathrm{aA}$ & $0.410 \mathrm{bA}$ & $4.125 \mathrm{cA}$ & $2.500 \mathrm{aA}$ & $0.252 \mathrm{aA}$ & $0.552 \mathrm{aA}$ \\
\hline $40 \%$ & $55 \mathrm{aA}$ & $75 \mathrm{cA}$ & $0.420 \mathrm{aA}$ & $0.687 \mathrm{cA}$ & $2.375 \mathrm{bA}$ & $1.887 \mathrm{aA}$ & $0.537 \mathrm{aA}$ & $0.667 \mathrm{aA}$ \\
\hline $50 \%$ & $75 \mathrm{aA}$ & $50 \mathrm{bA}$ & $0.547 \mathrm{aA}$ & $0.435 \mathrm{bA}$ & $2.770 \mathrm{bA}$ & $1.900 \mathrm{aA}$ & $0.397 \mathrm{aA}$ & $0.692 \mathrm{aA}$ \\
\hline Average & 53.33 & 42.50 & 0.376 & 0.367 & 2.523 & 1.499 & 0.421 & 0.658 \\
\hline CV $(\%)$ & 35.35 & 50.71 & 36.984 & 53.012 & 40.792 & 44.126 & 22.475 & 21.370 \\
\hline \multicolumn{9}{|c|}{ Experiment 2} \\
\hline $0 \%$ & $10 \mathrm{aA}$ & $15 \mathrm{aA}$ & $0.085 \mathrm{aA}$ & $0.142 \mathrm{aA}$ & $0.500 \mathrm{aA}$ & $0.625 \mathrm{aA}$ & $0.500 \mathrm{aA}$ & $0.417 \mathrm{aA}$ \\
\hline $10 \%$ & $35 \mathrm{bA}$ & $30 \mathrm{aA}$ & $0.342 \mathrm{bA}$ & $0.177 \mathrm{aA}$ & $2.165 \mathrm{bA}$ & $1.500 \mathrm{cA}$ & $0.650 \mathrm{aA}$ & $0.767 \mathrm{aA}$ \\
\hline $20 \%$ & $55 \mathrm{bA}$ & $50 \mathrm{aA}$ & $0.505 \mathrm{bA}$ & $0.452 \mathrm{aA}$ & $2.500 \mathrm{bA}$ & $3.915 \mathrm{bA}$ & $0.550 \mathrm{aA}$ & $0.275 \mathrm{aA}$ \\
\hline $30 \%$ & $85 \mathrm{cA}$ & $55 \mathrm{aA}$ & $0.680 \mathrm{cA}$ & $0.467 \mathrm{aA}$ & $3.350 \mathrm{bA}$ & $3.412 \mathrm{bA}$ & $0.335 \mathrm{aA}$ & $0.292 \mathrm{aA}$ \\
\hline $40 \%$ & $75 \mathrm{cA}$ & $70 \mathrm{aA}$ & $0.672 \mathrm{cA}$ & $0.635 \mathrm{aA}$ & $2.962 \mathrm{bA}$ & $2.470 \mathrm{bA}$ & $0.357 \mathrm{aA}$ & $0.512 \mathrm{aA}$ \\
\hline $50 \%$ & $60 \mathrm{bA}$ & $70 \mathrm{aA}$ & $0.497 \mathrm{bA}$ & $0.642 \mathrm{aA}$ & $4.165 \mathrm{cA}$ & $2.990 \mathrm{bA}$ & $0.242 \mathrm{aA}$ & $0.432 \mathrm{aA}$ \\
\hline Average & 53.33 & 48.33 & 0.4635 & 0.4192 & 2.607 & 2.4853 & 0.439 & 0.4491 \\
\hline CV (\%) & 46.77 & 41.66 & 44.146 & 47.187 & 43.599 & 45.252 & 31.797 & 36.506 \\
\hline
\end{tabular}

Note. Averages followed by the same upper case letter within a line and the same lower case letter within a column do not differ significantly according to Tukey's test at $\mathrm{P}<0.05$.

Treatments with $30 \%$ or more of water resulted in emergency percentage (E) of more than 50 in both varieties and in both experiments, being the highest index of the IAPAR variety with $85 \%$. However, the average of E (\%) in the treatments of IAPAR seeds was $53.33 \%$, like the study by Venturoso et al. (2015), which obtained a mean of $58.3 \%$ for the emergence of CV.

The EVI was maintained with averages close to the two lines in experiment 1 and increased in experiment 2, being the IAPAR with the highest result of 0.4635 seeds/day.

Abud et al. (2010a), obtained higher EVI values, being equal to 0.55 seeds/day in treatment with intermittent irrigation of seedlings of safflowers, being this value exceeded in this experiment in $20.83 \%$ of the treatments.

In relation to ATE, in experiment 1, both varieties showed higher averages in the $30 \%$ treatment; in the second experiment, there was no relation between treatments. The lowest MTE occurred in the $0 \%$ treatment for both periods and varieties, as fewer seedlings also decreased the initial and final counting time. In the sum of the means, the IMA2103 variety presented lower indexes, thus presenting greater uniformity in the emergency period.

The AVE in experiment 1 of treatment $10 \%$ in the variety IMA2103 presented the highest result, with 0.937 days $^{-1}$, being statistically different from the others.

With respect to the results of the morphological analysis of the plants at 30 days of sowing, it is possible to verify differentiation in the genotypes with significance at $5 \%$ probability only for the root length (RL) in treatments 10 and 20\% water addition, higher values for IMA2103 in experiment 1 (Table 3). 
Table 3. Average values of plant height (PH), root length (RL), stem diameter (SD), number of leaves (NL), fresh plant mass (FPM), fresh root mass (FRM), Plant dry mass (PDM) and Dry Root Mass (DRM) of seeds of IMA2103 and IAPAR varieties seeded on substrate and submitted to humidity of $0,10,20,30,40$ and $50 \%$ in Cascavel, Paraná, Brazil. May 2017

\begin{tabular}{|c|c|c|c|c|c|c|c|c|}
\hline \multirow{2}{*}{ Treatment } & \multicolumn{2}{|c|}{$\mathrm{PH}(\mathrm{cm})$} & \multicolumn{2}{|c|}{$\mathrm{RL}(\mathrm{cm})$} & \multicolumn{2}{|c|}{$\mathrm{SD}(\mathrm{mm})$} & \multicolumn{2}{|c|}{ NL } \\
\hline & IAPAR & IMA & IAPAR & IMA & IAPAR & IMA & IAPAR & IMA \\
\hline $0 \%$ & $9.40 \mathrm{aA}$ & $9.30 \mathrm{aA}$ & $18.00 \mathrm{aA}$ & $19.90 \mathrm{aA}$ & $1.37 \mathrm{aA}$ & $1.92 \mathrm{aA}$ & $4.00 \mathrm{aA}$ & $4.00 \mathrm{aA}$ \\
\hline $10 \%$ & $10.85 \mathrm{aA}$ & $12.20 \mathrm{aA}$ & $14.72 \mathrm{aA}$ & $30.43 \mathrm{aB}$ & $1.81 \mathrm{aA}$ & $1.86 \mathrm{aA}$ & $4.00 \mathrm{aA}$ & $4.00 \mathrm{aA}$ \\
\hline $20 \%$ & $12.32 \mathrm{aA}$ & $11.60 \mathrm{aA}$ & $15.87 \mathrm{aA}$ & $29.90 \mathrm{aB}$ & $2.00 \mathrm{aA}$ & $1.73 \mathrm{aA}$ & $4.50 \mathrm{aA}$ & $4.00 \mathrm{aA}$ \\
\hline $30 \%$ & $12.68 \mathrm{aA}$ & $9.00 \mathrm{aA}$ & $14.75 \mathrm{aA}$ & $18.92 \mathrm{aA}$ & $1.80 \mathrm{aA}$ & $1.84 \mathrm{aA}$ & 4.66aA & $4.00 \mathrm{aA}$ \\
\hline $40 \%$ & $11.18 \mathrm{aA}$ & $11.10 \mathrm{aA}$ & $17.13 \mathrm{aA}$ & $13.93 \mathrm{aA}$ & $1.73 \mathrm{aA}$ & $1.75 \mathrm{aA}$ & $4.00 \mathrm{aA}$ & $4.00 \mathrm{aA}$ \\
\hline $50 \%$ & $11.28 \mathrm{aA}$ & $11.00 \mathrm{aA}$ & $16.21 \mathrm{aA}$ & $8.60 \mathrm{aA}$ & $1.71 \mathrm{aA}$ & $1.61 \mathrm{aA}$ & $3.66 \mathrm{aA}$ & $4.00 \mathrm{aA}$ \\
\hline Average & 11.28 & 10.70 & 16.11 & 20.28 & 1.73 & 1.78 & 4.13 & 4.00 \\
\hline CV (\%) & 30.34 & 10.89 & 7.37 & 38.94 & 10.87 & 5.68 & 8.19 & 0.00 \\
\hline \multirow{2}{*}{ Treatment } & \multicolumn{2}{|c|}{ FPM $(\mathrm{g})$} & \multicolumn{2}{|c|}{ FRM $(\mathrm{g})$} & \multicolumn{2}{|c|}{ PDM $(\mathrm{g})$} & \multicolumn{2}{|c|}{ DRM $(\mathrm{g})$} \\
\hline & IAPAR & IMA & IAPAR & IMA & IAPAR & IMA & IAPAR & IMA \\
\hline $0 \%$ & $0.301 \mathrm{aA}$ & $0.340 \mathrm{aA}$ & $0.125 \mathrm{aA}$ & $0.089 \mathrm{aA}$ & $0.019 \mathrm{aA}$ & $0.031 \mathrm{aA}$ & $0.049 \mathrm{bA}$ & $0.031 \mathrm{aA}$ \\
\hline $10 \%$ & $0.462 \mathrm{aA}$ & $0.481 \mathrm{aA}$ & $0.118 \mathrm{aA}$ & $0.120 \mathrm{aA}$ & $0.029 \mathrm{aA}$ & $0.022 \mathrm{aA}$ & $0.016 \mathrm{cA}$ & $0.012 \mathrm{aA}$ \\
\hline $20 \%$ & $0.474 \mathrm{aA}$ & $0.408 \mathrm{aA}$ & $0.262 \mathrm{aA}$ & $0.145 \mathrm{aA}$ & $0.026 \mathrm{aA}$ & $0.020 \mathrm{aA}$ & $0.010 \mathrm{aA}$ & $0.015 \mathrm{aA}$ \\
\hline $30 \%$ & $0.528 \mathrm{aA}$ & $0.375 \mathrm{aA}$ & $0.084 \mathrm{aA}$ & $0.108 \mathrm{aA}$ & $0.023 \mathrm{aA}$ & $0.018 \mathrm{aA}$ & $0.007 \mathrm{aA}$ & $0.011 \mathrm{aA}$ \\
\hline $40 \%$ & $0.448 \mathrm{aA}$ & $0.383 \mathrm{aA}$ & $0.098 \mathrm{aA}$ & $0.066 \mathrm{aA}$ & $0.020 \mathrm{aA}$ & $0.015 \mathrm{aA}$ & $0.008 \mathrm{aA}$ & $0.010 \mathrm{aA}$ \\
\hline $50 \%$ & $0.381 \mathrm{aA}$ & $0.495 \mathrm{aA}$ & $0.244 \mathrm{aA}$ & $0.063 \mathrm{aA}$ & $0.019 \mathrm{aA}$ & $0.012 \mathrm{aA}$ & $0.018 \mathrm{cA}$ & $0.016 \mathrm{aA}$ \\
\hline Average & 0.432 & 0.413 & 0.155 & 0.098 & 0.022 & 0.019 & 0.018 & 0.015 \\
\hline CV (\%) & 16.864 & 13.619 & 45.516 & 29.661 & 16.637 & 30.602 & 80.187 & 44.869 \\
\hline
\end{tabular}

Note. Averages followed by the same upper-case letter within a line and the same lower-case letter within a column do not differ significantly according to Tukey's test at $\mathrm{P}<0.05$.

The RL may have been influenced by the density of emerged seedlings, since in the treatments with higher E, resulted in greater root development, corroborating with Corrêa et al. (2014), which associates the reduction of fresh root mass and the reduction in root size to the increase of planting density, causing competition for light and nutrients among beet plants.

The lowest value of OS and FAM was verified at $0 \%$ (control) humidity for both genotypes in experiment 1 , evidencing the necessity of irrigation for the initial development of the seedlings of safflowers, although Kizil et al. (2008) and Dantas et al. (2011) cite their resistance to water deficiency.

Regarding the genotypes, the IAPAR obtained in the treatments of 20 and $30 \%$ of humidity, the best results of PS, SD, NL and FAM. For the IMA2103 variety, treatments 10 and 20\% presented higher PS, RL and FRM values. The best performance of the varieties to the treatments of smaller amount of irrigation can be related to the greater aeration of the substrate, because greater availability of water to the soil can promote reduction in the supply of oxygen to the roots, inhibiting the root development (Paiva Sobrinho, Tieppo, \& Silva, 2011).

For both varieties FRM and DRM were found higher results for the treatments with lower water availability, which can be explained by the higher growth of the roots in search of humidity.

However, the values of SD and NL did not show large variations even for the $0 \%$ water treatment. In the experiment 2 , it is possible to verify differentiation in the genotypes with significance to $5 \%$ probability only for the Diameter of the Stem (SD) with the highest values for the IAPAR variety in the treatments of 20 to $50 \%$ of humidity (Table 4). 
Table 4. Mean values of plant height (PH), root length (RL), stem diameter (SD), number of leaves (NL), fresh plant mass (FPM), fresh root mass (FRM), Plant dry mass (PDM) and Dry Root Mass (DRM) of seeds of IMA2103 and IAPAR varieties seeded on substrate and submitted to moisture of $0,10,20,30,40$ and $50 \%$ in Cascavel, Paraná, Brazil. June 2017

\begin{tabular}{|c|c|c|c|c|c|c|c|c|}
\hline \multirow{2}{*}{ Treatment } & \multicolumn{2}{|c|}{$\mathrm{PH}(\mathrm{cm})$} & \multicolumn{2}{|c|}{$\mathrm{RL}(\mathrm{cm})$} & \multicolumn{2}{|c|}{$\mathrm{SD}(\mathrm{mm})$} & \multicolumn{2}{|c|}{ NL } \\
\hline & IAPAR & IMA & IAPAR & IMA & IAPAR & IMA & IAPAR & IMA \\
\hline $0 \%$ & - & $10.000 \mathrm{aA}$ & - & $14.400 \mathrm{aA}$ & - & $0.865 \mathrm{aA}$ & - & $3.000 \mathrm{aA}$ \\
\hline $10 \%$ & $12.450 \mathrm{aA}$ & $8.950 \mathrm{aA}$ & $20.800 \mathrm{aA}$ & $27.200 \mathrm{aA}$ & $1.908 \mathrm{aA}$ & $1.215 \mathrm{aA}$ & $4.000 \mathrm{aA}$ & $4.000 \mathrm{aA}$ \\
\hline $20 \%$ & $12.366 \mathrm{aA}$ & $9.740 \mathrm{aA}$ & $19.950 \mathrm{aA}$ & $21.500 \mathrm{cA}$ & $2.078 \mathrm{aB}$ & $1.212 \mathrm{aA}$ & $3.666 \mathrm{aA}$ & $3.600 \mathrm{aA}$ \\
\hline $30 \%$ & $13.150 \mathrm{aA}$ & $11.216 \mathrm{aA}$ & $18.633 \mathrm{aA}$ & $19.183 \mathrm{cA}$ & $1.881 \mathrm{aB}$ & $1.108 \mathrm{aA}$ & $4.000 \mathrm{aA}$ & $3.666 \mathrm{aA}$ \\
\hline $40 \%$ & $10.780 \mathrm{aA}$ & $11.166 \mathrm{aA}$ & $18.400 \mathrm{aA}$ & $21.316 \mathrm{cA}$ & $1.838 \mathrm{aB}$ & $1.165 \mathrm{aA}$ & $3.600 \mathrm{aA}$ & $3.666 \mathrm{aA}$ \\
\hline $50 \%$ & $11.183 \mathrm{aA}$ & $12.416 \mathrm{aA}$ & $13.883 \mathrm{aA}$ & $14.883 \mathrm{cA}$ & $1.945 \mathrm{aB}$ & $1.130 \mathrm{aA}$ & $3.666 \mathrm{aA}$ & $3.666 \mathrm{aA}$ \\
\hline Average & 11.985 & 10.581 & 18.333 & 19.747 & 1.930 & 1.115 & 3.786 & 3.599 \\
\hline CV (\%) & 7.286 & 10.787 & 13.044 & 22.039 & 4.239 & 10.646 & 4.649 & 8.280 \\
\hline \multirow{2}{*}{ Treatment } & \multicolumn{2}{|c|}{ FPM $(\mathrm{g})$} & \multicolumn{2}{|c|}{ FRM $(\mathrm{g})$} & \multicolumn{2}{|c|}{ PDM $(\mathrm{g})$} & \multicolumn{2}{|c|}{ DRM $(\mathrm{g})$} \\
\hline & IAPAR & IMA & IAPAR & IMA & IAPAR & IMA & IAPAR & IMA \\
\hline $0 \%$ & - & $0.289 \mathrm{aA}$ & - & $0.198 \mathrm{aA}$ & - & $0.018 \mathrm{aA}$ & - & $0.097 \mathrm{bA}$ \\
\hline $10 \%$ & $0.599 \mathrm{aA}$ & $0.379 \mathrm{aA}$ & $0.165 \mathrm{aA}$ & $0.166 \mathrm{aA}$ & $0.040 \mathrm{aA}$ & $0.020 \mathrm{aA}$ & $0.018 \mathrm{aA}$ & $0.035 \mathrm{aA}$ \\
\hline $20 \%$ & $0.554 \mathrm{aA}$ & $0.413 \mathrm{aA}$ & $0.160 \mathrm{aA}$ & $0.131 \mathrm{aA}$ & $0.029 \mathrm{aA}$ & $0.042 \mathrm{aA}$ & $0.021 \mathrm{aA}$ & $0.021 \mathrm{aA}$ \\
\hline $30 \%$ & $0.610 \mathrm{aA}$ & $0.487 \mathrm{aA}$ & $0.171 \mathrm{aA}$ & $0.151 \mathrm{aA}$ & $0.028 \mathrm{aA}$ & $0.025 \mathrm{aA}$ & $0.020 \mathrm{aA}$ & $0.196 \mathrm{aA}$ \\
\hline $40 \%$ & $0.374 \mathrm{aA}$ & $0.449 \mathrm{aA}$ & $0.106 \mathrm{aA}$ & $0.118 \mathrm{aA}$ & $0.028 \mathrm{aA}$ & $0.024 \mathrm{aA}$ & $0.026 \mathrm{aA}$ & $0.015 \mathrm{aA}$ \\
\hline $50 \%$ & $0.507 \mathrm{aA}$ & $0,546 \mathrm{aA}$ & $0.091 \mathrm{aA}$ & $0.101 \mathrm{aA}$ & $0.030 \mathrm{aA}$ & $0.026 \mathrm{aA}$ & $0.010 \mathrm{aA}$ & $0.014 \mathrm{aA}$ \\
\hline Average & 0.5288 & 0.427 & 0.138 & 0.144 & 0.031 & 0.025 & 0.019 & 0.063 \\
\hline CV (\%) & 16.178 & 19.063 & 24.001 & 22.194 & 14.711 & 30.019 & 27.449 & 104.685 \\
\hline
\end{tabular}

Note. Averages followed by the same upper-case letter within a line and the same lower-case letter within a column do not differ significantly according to Tukey's test at $\mathrm{P}<0.05$. (-) Plants that did not emerge.

In this experiment, no seedling of the IAPAR lineage survived until 30 days of the sowing in the treatment without irrigation to perform the morphological analysis, thus, it is not possible to compare the genotypes.

The PS and FPM values were higher in the $30 \%$ treatment for the IAPAR variety and $50 \%$ for the IMA2 103 . And the RL was superior for the two genotypes for the treatment at $10 \%$ of humidity, emphasizing in both experiments, greater development of the same ones in water deficit.

For the other treatments there was no direct relationship between moisture and values of morphological variables. This variation of seedling behavior can be explained by the variation of seed size, since it can influence seed vigor, which according to Carvalho and Nakagawa (2000) reports the larger seed size is generally related to better formed embryos and with greater amount of reserves, presenting better vigor. However, according to Abud et al. (2010a), seed size does not influence emergence, velocity and mean time of emergence of seedlings, suggesting the mixing of sowing sizes.

\section{Conclusion}

The treatment without irrigation showed less emergency percentage and emergency speed index for two genotypes.

Seedling emergence was higher than $50 \%$ in treatments above $30 \%$ of water availability, in both varieties.

Lower irrigation rates favored root length and dry root mass.

\section{References}

Abud, F. H., Reis, R. D. G. E., Innecco, R., \& Bezerra, A. M. E. (2010a). Emergência e desenvolvimento de plântulas de cártamos em função do tamanho das sementes. Revista Ciência Agronômica, 41(1), 95-99.

Abud, H. F., Gonçalves, N. R., Reis, R. de G. E., Gallão, M. I., \& Innecco, R. (2010b). Morfologia de sementes e plântulas de cártamo. Revista Ciência Agronômica, 41(2), 259-265. 
Beltrão, N. E. de M., Fideles Filho, J., \& Figueirêdo, I. C. de M. (2002). Uso adequado de casa-de-vegetação e de telados na experimentação agrícola. Revista Brasileira de Engenharia Agrícola e Ambiental, 6(3), 547-552. https://doi.org/10.1590/S1415-43662002000300029

Carvalho, N. M., \& Nakagawa, J. (2000). Sementes: ciência, tecnologia e produção. Jaboticabal: FUNEP.

Corrêa, C. V., Cardoso, A. I. I., Souza, L. G., Antunes, W. L. P., \& Magolbo, L. A. (2014). Produção de beterraba em função do espaçamento. Horticultura Brasileira, 32, 111-114. https://doi.org/10.1590/S0102-05362014 000100019

Dantas, C. V. S., Silva, I. B., Pereira, G. M., Maia, J. M., Lima, J. P. M. S., \& Macedo, C. E. C. (2011). Influência da sanidade e déficit hídrico na germinação de sementes de Carthamus tinctorius L. Revista Brasileira de Sementes, 33(3), 574-582. https://doi.org/10.1590/S0101-31222011000300020.

Emongor, V. (2010). Safflower (Carthamus tinctorius L.) the underutilized and neglected crop: A review. Asian Journal of Plant Sciences, 9, 299-306. https://doi.org/10.3923/ajps.2010.299.306

Ferreira, D. F. (2011). Sisvar: A computer statistical analysis system. Ciência e Agrotecnologia, 35(6), 1039-1042. https://doi.org/10.1590/S1413-70542011000600001

Guo, J., Ling, H., Wu, Q., Xu, L., \& Que, Y. (2014). The choice of reference genes for assessing gene expression in sugarcane under salinity and drought stresses. Scientific Reports, 4, 7042. https://doi.org/10.1038/ srep07042

Kizil, S., Cakmak, O., Kirici, S., \& Inan, M. (2008). Comprehensive study on Safflower (Carthamus tinctorius L.) in semi-arid conditions. Biotechnology \& Biotechnological Equipment, 4(1), 947-953. https://doi.org/ 10.1080/13102818.2008.10817585

Labouriau, L. G., \& Valadares, M. E. B. (1976). Onth egermination of seeds Calotropis procera (Ait.) Ait.f. Anais da Academia Brasileira de Ciências, 48(2), 263-284.

Maguire, J. D. (1962). Speed germination-aid in selection and evaluation for seedling emergence and vigor. Crop Sci., 2, 176-177. https://doi.org/10.2135/cropsci1962.0011183X000200020033x

Moterle, L. M., Scapim, C. A., Braccini, A. L., Rodovalho, M. A., \& Barreto, R. R. (2008). Influência do estresse hídrico sobre o desempenho fisiológico de sementes de híbridos simples de milho-pipoca. Ciência e Agrotecnologia, 32, 1810-1817.https://doi.org/10.1590/S1413-70542008000600020

Neto, G. F. da S., Machado, G. A., Lima, C. V. L., Santos, A. T. L., \& Alberto, C. M. (2012). Quantidade de grãos de cartamo produzidos em função do excesso hídrico. Anais do Salão Internacional de Ensino, Pesquisa e Extensão, 4, 2.

Paiva Sobrinho, S., Tieppo, R. C., \& Silva, T. J. A. (2011). Desenvolvimento inicial de plantas de girassol em condições de estresse hídrico, Enciclopédia Biosfera, 7, 1-12.

Singh, R. J. (2006). Safflower (Carthamus tinctorius L.), genetic resources, chromosome engineering, and crop improvement (Vol. 4). CRC, New York.

Singh, V., \& Nimbkar, N. (2016). Safflower. Breeding Oilseed Crops for Sustainable Production (pp. 149-167). https://doi.org/10.1007/s13593-015-0344-8

Venturoso, L. dos R., Bacchi, L. M. A., Gavassoni, W. L., Venturoso, L. A. C., Pontim, B. C. A., \& Reis, G. F. dos (2015). Inoculação de Sclerotinia sclerotiorum em sementes de oleaginosas: Transmissão e seus efeitos sobre a emergência de plantas. Ciência Rural, 45(5), 788-793. https://doi.org/10.1590/0103-8478cr 20140374

\section{Copyrights}

Copyright for this article is retained by the author(s), with first publication rights granted to the journal.

This is an open-access article distributed under the terms and conditions of the Creative Commons Attribution license (http://creativecommons.org/licenses/by/4.0/). 